\title{
Clinical Implications of Tumor Necrosis Factor-Alpha, Interleukin-6 and Resistin in Coronary Artery Disease
}

\author{
Qamar Javed \\ Department of Biochemistry, Quaid-i-Azam University, Islamabad, Pakistan \\ Email: qjaved6@gmail.com
}

Received 23 May 2014; revised 5 June 2014; accepted 1 July 2014

Copyright (C) 2014 by author and Scientific Research Publishing Inc.

This work is licensed under the Creative Commons Attribution International License (CC BY).

http://creativecommons.org/licenses/by/4.0/

(c) (i) Open Access

\begin{abstract}
Tumor necrosis factor alpha (TNF-alpha) and interleukin-6 (IL-6) are involved in the progression of coronary artery disease (CAD). The cytokines' levels are associated with the severity of CAD. We have recently reported on the association of resistin, a relatively novel cytokine with the pathogenesis of cardiovascular disease (CVD). Although the inflammatory cytokines' impact on atherosclerosis is widely accepted, yet some controversy exists regarding the involvement of these factors in atherogenesis. The current review highlights the potential association of TNF-alpha, IL-6 and resistin SNPs (single nucleotide polymorphisms) with CAD. Molecular genetics data along with the intracellular signaling cascade mechanisms may have important clinical implications in the treatment of CAD.
\end{abstract}

\section{Keywords}

Tumor Necrosis Factor-Alpha, Interleukin-6, Resistin, Coronory Heart Disease, Gene Polymorphism

\section{Atheroma Formation and Inflammation}

Cardiovascular disease (CVD) has gradually become one of the major causes of death worldwide. Atherosclerosis and resulting clinical complications are complex pathophysiologic processes involving a variety of genes and gene products in complicated interactions with environmental influences [1]. According to the WHO health report 2008, global estimates of mortality due to CVD are predicted to rise from 17.1 million in 2004 to 23.4 million in 2030. A range of genetic and environmental factors appear to participate in the pathogenesis of coronary artery disease (CAD). A number of cardiovascular risk factors and other markers of cardiac stress and malfunction, as well as myocyte injury appear to have growing clinical importance. Some cardiovascular biomarkers 
could be risk factors themselves and therefore may be potential targets of therapy [2]. A role for inflammation has become well established in the development of CAD over the past couple of decades. In particular, inflammatory responses to arterial injury resulted in the recruitment and activation of monocytes mainly through activation of the monocyte chemoattractantprotein-1 (MCP-1) pathway have a central role in atherogenesis [3]. Atherosclerotic lesions are asymmetric focal thickenings of the innermost layer of the artery consisting of cells, connective-tissue elements, lipids, and debris [4]. In addition to these components, blood borne inflammatory and immune cells along with vascular endothelial and smooth-muscle cells constitute an important part of the atheroma. There is a close relation between atherogenesis and inflammation. Inflammatory mediators are found to be not only responsible for the contribution to the atheroma formation, but may also affect in the rapid evolution of the atheromatous injury, leading to plaque rupture, nitrous oxide production and thrombosis. In this sense, it is worth noting that several cytokines may play a role in determining the degree of inflammation and contributing to atherogenesis [5]. Thus, from a pathological perspective, initiation, growth, and complication of the atherosclerotic plaque, may be considered as an inflammatory response to injury [6]. While traditional risk factors still prevail, newer risk factors are also emerging.

\section{Tumor Necrosis Factor-Alpha}

The inflammatory cytokine, TNF-alpha, is considered to play a role in the development of CVD [7] [8]. The over expression of TNF-alpha has been implicated in the pathogenesis of several conditions including arthritis, CAD and myocardial dysfunction [9] [10]. TNF-alpha is known to exert a range of inflammatory and immunomodulatory activities in vivo. Currently, the focus is on the mechanisms that modulate TNF-alpha production, which in turn impact on the inflammation-mediated disease process. Various polymorphisms have been identified within and around the TNF-alpha encoding gene located within the major histocompatibility complex (MHC). In the promoter region relative to the transcription start site, there are several single nucleotide polymorphisms (SNPs), at positions $-1031\left(\mathrm{~T}^{*} \mathrm{C}\right),-863\left(\mathrm{C}^{*} \mathrm{~A}\right),-857\left(\mathrm{C}^{*} \mathrm{~A}\right),-851\left(\mathrm{C}^{*} \mathrm{~T}\right),-419\left(\mathrm{G}^{*} \mathrm{C}\right),-376\left(\mathrm{G}^{*} \mathrm{~A}\right)$, $-308\left(G^{*} A\right),-238\left(G^{*} A\right)$, and $-163\left(G^{*} A\right)$. A single gene polymorphism could contribute to the overall risk of cardiovascular events. Polymorphisms at position $-308\left(G^{*} A\right)$ and $-238\left(G^{*} A\right)$ have been shown to be associated with CVD [11]. Cardiovascular complications may be influenced by TNF-alpha gene polymorphisms [12]. Elevated TNF-alpha levels have consistently been reported in patients with heart failure and increasing concentrations of the cytokine are related with the severity of CVD and mortality rate in the patients [13] [14]. Some of the TNF-alpha gene polymorphisms have direct effect on gene transcription and protein function. However, certain studies failed to find a significant association between the TNF-alpha gene polymorphisms and CVD [15] [16]. Further in-depth studies and haplotype analysis are required to resolve this controversy.

\section{Interleukin-6}

The molecular mechanisms involved in the pathogenesis of CAD are still not fully understood. However, there is a consensus that the main events of unstable angina and myocardial infarction are due to the involvement of major inflammatory cytokines. Besides TNF-alpha, IL-6 also has a significant role in the development of CAD. IL-6 is associated with the process of inflammation, and it up-regulates the synthesis of the acute phase proteins involved in the process of inflammation [17]. Several reports have linked systemic inflammation and CVD [18]. Patients with high levels of IL-6 show a worse in-hospital outcome following treatment in case of unstable angina [19] [20]. Cardiovascular risk factors like smoking and physiological stress increase the levels of IL-6 in plasma [21] [22]. IL-6 expression may determine the magnitude of inflammation and its correlation with CVD. The major breakthrough of IL-6 gene polymorphism has been shown to determine the levels of IL-6 production in the body [23]. An association has been shown between the IL-6 promoter polymorphism -174G/C and left ventricular hypertrophy $(\mathrm{LVH})$ and hypertension in patients [24]. This polymorphism also shows association with CAD [25]. IL-6 gene polymorphisms (-174G > C, $-572 \mathrm{G}>\mathrm{C}$ and $-597 \mathrm{G}>\mathrm{A}$ ) are strong predictors of the cytokine concentrations in plasma following inflammatory stimulus, which is clinically relevant in patients with CVD [26].

\section{Resistin}

Recent investigations have highlighted the involvement of a novel cytokine, resistin, in the pathogenesis of CVD 
[27] [28]. The resistin gene (RETN) polymorphism at -420 and +299 leads to increased concentrations of the peptide in circulation, which is associated with cardiomyopathy and CAD. CVD patients with the RETN variant alleles, in addition to elevated inflammatory markers resistin and high sensitivity C-reactive protein, showed significantly high levels of primary risk factors e.g. total cholesterol, low-density lipoprotein, triglycerides and low concentrations of high-density lipoprotein. It appears that besides primary risk factors, resistin cytokine may be a risk factor for CVD. Taken together these risk factors could have a pronounced effect on cardiovascular pathology.

CVD history is another risk factor of the disease. Evidence shows that there is an increased risk of coronary complications in healthy siblings of patients with CAD [28]. Interestingly, healthy subjects from families with

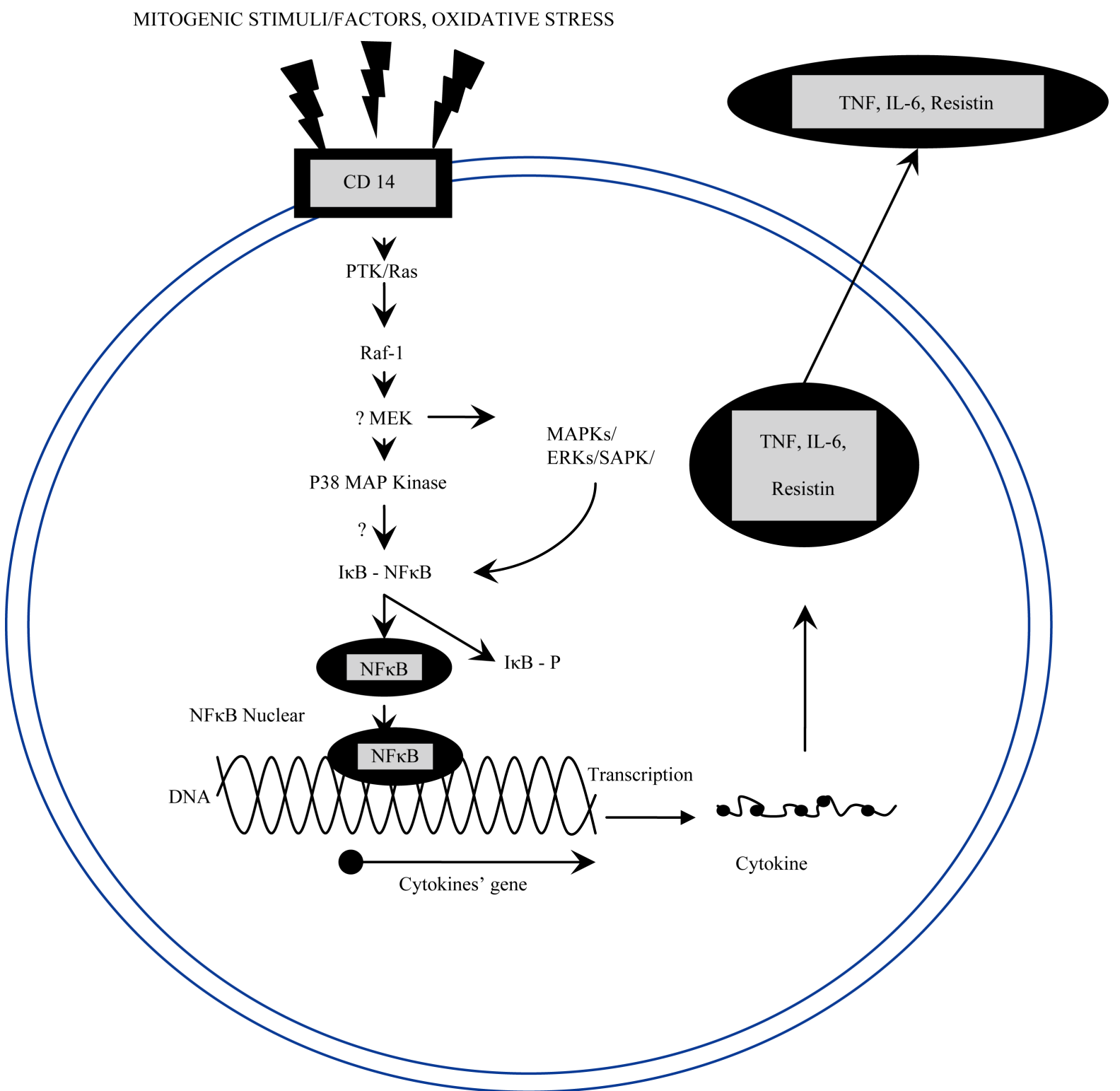

Figure 1. Intracellular signaling pathway. Mitogenic factors and oxidative stress activate the CD 14 receptor to induce cytokines expression (e.g. TNF, IL-6 and resistin). These stimuli lead to tyrosine phosphorylation of Ras by phosphotyrosine kinase (PTK); the protein kinase cascade leads to cytokines' production. Ras activates Raf-1/mitogen-activated protein kinase, followed by the activation of the mitogen-activated protein kinase (MAPK) family of protein kinases, extracellular signal-related kinase (ERKs), stress-activated protein kinase (SAPK), and jun nuclear kinase (JNK) and the P38 MAPK. $\mathrm{NF} \kappa \mathrm{B}$ is activated by phosphorylation and translocates to the nucleus to activate promoter sites. 
CAD history had a higher frequency of the RETN -420G variant allele [28] compared with the individuals without disease history [6]. It is probable that the disease-susceptible alleles among healthy subjects may predispose them to the disease. Genetic makeup can influence the disease pathology as evidenced from a crosssectional study demonstrating lowest rates of CVD from the Chinese Canadians compared with European Canadians with the moderate disease rates [29].

\section{Role of Cytokines Signaling Pathway in CAD}

Intracellular signaling pathways propagate downstream events in the regulation of gene expression. A functional genetic variant in the promoter region of the above mentioned inflammatory markers may affect the cytokines' levels via the p38 mitogen-activated protein kinase (p38 MAPK) signaling involving nuclear factor kappa B $(\mathrm{NF} \kappa \mathrm{B})$ cascade loop (Figure 1). Hence from this aspect, SNPs may lead to elevated gene expression of inflammatory cytokines which could influence clinical outcome in patients with CAD. Molecular mechanisms that provide insights into the role of inflammatory markers have been a focus of immense interest in recent studies. Genome-wide association studies (GWAS) indicate that SNPs on 9p21 (Chr9p21) contribute to susceptibility of CAD [30]-[32]. Cytokines' haplotypes comprising of CAD-susceptible alleles could significantly affect the disease pathophysiology by up-regulating the inflammatory markers expression. Furthermore, evidence shows that methylation of P15INK4B appears to be involved in the pathogenesis of CAD [33]. This suggests that promoter region methylation is another factor that may influence gene expression. Since less information is available regarding post-transcriptional regulation of candidate genes of CAD, further studies from this perspective may help in elucidating the molecular basis of the disease pathology. A better understanding of the genetic control of the inflammatory processes could have useful clinical implications. Genetic makeup of patients determines the clinical outcome in response to the disease treatment [34]. Molecular investigations based on the disease-susceptible genes and their pathophysiological influences on the pathogenesis of the disease are warranted to limit $\mathrm{CAD}$ and other CVD complications which are currently increasing globally.

\section{Acknowledgements}

Cytokines study in our laboratory was supported by the Pakistan Science Foundation and the Higher Education Commission of Pakistan.

\section{References}

[1] Tracy, R.P. (2003) Thrombin, Inflammation and Cardiovascular Disease. Chest, 124, 49S-57S. http://dx.doi.org/10.1378/chest.124.3 suppl.49S

[2] Braunwald, E. (2008) Review Article: Biomarkers in Heart Failure. New England Journal of Medicine, 358, $2148-2159$. http://dx.doi.org/10.1056/NEJMra0800239

[3] Egashira, K. (2003) Molecular Mechanisms Mediating Inflammation in Vascular Disease: Special Reference to Monocyte Chemoattractant Protein-1. Hypertension, 41, 834-841. http://dx.doi.org/10.1161/01.HYP.0000051642.65283.36

[4] Hansson, G.K. (2005) Review Article: Inflmmation, Atherosseclerosis and Coronary Artery Disease. New England Journal of Medicine, 352, 1685-1695. http://dx.doi.org/10.1056/NEJMra043430

[5] Padovani, J.C., Pazin-Filho, A., Simoes, M.V., Marin-Neto, J.A., Zago, M.A. and Franco, R.F. (2000) Gene Polymorphisms in the TNF Locus and the Risk of Myocardial Infarction. Thrombosis Research, 100, 263-269. http://dx.doi.org/10.1016/S0049-3848(00)00315-7

[6] Pearson, T.A., George, A., Mensah, G.A., Alexander, R.W., Anderson, J.L., Cannon, R.O., et al. (2003) Markers of Inflammation and Cardiovascular Disease: Application to Clinical and Public Health Practice; A Statement for Healthcare Professionals from the Centers for Disease Control and Prevention and the American Heart Association. Circulation, 107, 499-511. http://dx.doi.org/10.1161/01.CIR.0000052939.59093.45

[7] Calabrese, F., Elisa, C., Cristina, C., et al. (2004) Over Expression of Tumor Necrosis Factor (TNF-a) and TNF-a Receptor-1 in Human Viral Myocarditis: Clinicopathologic Correlations. Mordern Pathology, 17, 1108-1118. http://dx.doi.org/10.1038/modpathol.3800158

[8] Levine, B., Kalman, J., Mayer, L., et al. (1990) Elevated Circulating Levels of Tumor Necrosis Factor in Severe Chronic Heart Failure. New England Journal of Medicine, 323, 236-241.

http://dx.doi.org/10.1056/NEJM199007263230405 
[9] Elahi, M.M. and Matata, B.M. (2005) Genetic Diversity of Tumour Necrosis Factor: Implications on Cardiovascular Complications of Polymorphisms at Position -308 in the Promoter Region. The Cardiology, 1, 179-188.

[10] Brinkman, B.M. (1996) Relevance of the Tumor Necrosis Factor Alpha (TNF Alpha) -308 Promoter Polymorphism in TNF Alpha Gene Regulation. Journal of Inflammation, 46, 32-41.

[11] Patel, R., Lim, D.S., Reddy, D., Nagueh, S.F., Lutucuta, S., Sole, M.J., et al. (2000) Variants of Trophic Factors and Expression of Cardiac Hypertrophy in Patients with Hypertrophic Cardiomyopathy. Journal of Molecular and Cellular Cardiology, 32, 2369-2377. http://dx.doi.org/10.1038/sj.ejhg.5201816

[12] Mellick, G.D. (2007) TNF Gene Polymorphism and Quantitative Trait Related to Cardiovascular Diseases: Getting to the Heart of the Matter. European Journal of Human Genetics, 15, 609-611. http://dx.doi.org/10.1038/sj.ejhg.5201816

[13] Deswal, A., Petersen, N.J., Feldman, A.M., Young, J.B., White, B.G. and Mann, D.L. (2001) Cytokines and Cytokine Receptors in Advanced Heart Failure: An Analysis of the Cytokine Database from the Vesnarinone Trial (VEST). Circulation, 103, 2055-2059. http://dx.doi.org/10.1161/01.CIR.103.16.2055

[14] Torre-Amione, G., Kapadia, S., Benedict, C., Oral, H., Young, J.B. and Manna, D.L. (1996) Proinflammatory Cytokine Levels in Patients with Depressed Left Ventricular Ejection Fraction: A Report from the Studies of Left Ventricular Dysfunction (SOLVD). Journal of American College of Cardiology, 27, 1201-1206.

http://dx.doi.org/10.1016/0735-1097(95)00589-7

[15] Kubota, T., McNamara, D.M., Wang, J.J., Trost, M., McTiernan, C.F., Mann, D.L., et al. (1998) Effects of Tumor Necrosis Factor Gene Polymorphisms on Patients with Congestive Heart Failure. Circulation, 97, 2499-2501. http://dx.doi.org/10.1161/01.CIR.97.25.2499

[16] Bidwell, J., Keen, L., Gallagher, G., Kimberly, R., Huizinga, T., McDermott, M.F., et al. (1999) Cytokine Gene Polymorphism in Human Disease: On-Line Databases. Immunology, 1, 3-19.

[17] Castell, J.V., Gómez-Lechón, M.J., David, M., Andus, T., Geiger, T., Trullenque, R., et al. (1989) Interleukin-6 Is the Major Regulator of Acute Phase Protein Synthesis in Adult Human Hepatocytes. FEBS Letters, 242, 237-239. http://dx.doi.org/10.1016/0014-5793(89)80476-4

[18] Harris, T.B., Ferrucci, L., Tracy, R.P., Corti, M.C., Wacholder, S., Ettinger, W.H., et al. (1999) Associations of Elevated Interleukin-6 and C-Reactive Protein in Levels with Mortality in the Elderly. American Journal of Medicine, 106, 506-512. http://dx.doi.org/10.1016/S0002-9343(99)00066-2

[19] Biasucci, L.M., Liuzzo, G., Grillo, R.L., Caligiuri, G., Rebuzzi, A.G., Buffon, A., et al. (1999) Elevated Levels of CReactive Protein at Discharge in Patients with Unstable Angina Predict Recurrent Instability. Circulation, 99, 855-860. http://dx.doi.org/10.1161/01.CIR.99.7.855

[20] Biasucci, L.M., Liuzzo, G., Fantuzzi, G., Caligiuri, G., Rebuzzi, A.G., Ginnetti, F., et al. (1999) Increasing Levels of Interleukin (1L)-1Ra and IL-6 during the First Two Days of Hospitalization in Unstable Angina Are Associated with Increased Risk of IN-Hospital Coronary Events. Circulation, 99, 2079-2084. http://dx.doi.org/10.1161/01.CIR.99.16.2079

[21] Tappia, P.S., Man, W.J. and Grimble, R.F. (1995) Influence of Unsaturated Fatty Acids on the Production of Tumour Necrosis Factor and Interleukin-6 by Rat Peritoneal Macrophages. Molecular and Cell Biochemistry, 143, 89-98. http://dx.doi.org/10.1007/BF01816941

[22] Maes, M., Song, C., Lin, A., De Jongh, R., Van Gastel, A., Kenis, G., et al. (1998) The Effects of Psychological Stress on Humans: Increased Production of Pro-Inflammatory Cytokines and Th1-Like Response in Stress-Induced Anxiety. Cytokine, 10, 313-318. http://dx.doi.org/10.1006/cyto.1997.0290

[23] Fishman, D., Faulds, G., Jeffery, R., Mohamed-Ali, V., Yudkin, J.S., Humphries, S., et al. (1998) The Effect of Novel Polymorphisms in the Interleukin-6 (IL-6) Gene on IL-6 Transcription and Plasma IL-6 Levels, and an Association with Systemic-Onset Juvenile Chronic Arthritis. Journal of Clinical Investigation, 102, 1369-1376. http://dx.doi.org/10.1172/JCI2629

[24] Losito, A., Kalidas, K., Santoni, S. and Jeffery, S. (2003) Association of Interleukin-6 -174G/C Promoter Polymorphism with Hypertension and Left Ventricular Hypertrophy in Dialysis Patients. Kidney International, 64, 616-622. http://dx.doi.org/10.1046/j.1523-1755.2003.00119.x

[25] Humphries, S.E., Luong, L.A., Ogg, M.S., Hawe, E. and Miller, G.J. (2001) The Interleukin-6 174 G/C Polymorphism Is Associated with Risk of Coronary Heart Disease and Systolic Blood Pressure in Healthy Men. European Heart Journal, 22, 2243-2252. http://dx.doi.org/10.1161/hq0901.094280

[26] Brull, D.J., Montgomery, H.E., Sanders, J., Dhamrait, S., Luong, L., Rumley, A., et al. (2001) Interleukin-6 Gene -174G > C and -572G > C Promoter Polymorphisms Are Strong Predictors of Plasma Interleukin-6 Levels after Coronary Artery Bypass Surgery. Arteriosclerosis, Thrombosis, and Vascular Biology, 21, 1458-1463. http://dx.doi.org/10.1161/hq0901.094280

[27] Hussain, M., Asghar, M. and Javed, Q. (2010) Resistin Gene Promoter Region Polymorphism and the Risk of Hyper- 
trophic Cardiomyopathy in Patients. Translational Research, 155, 142-147. http://dx.doi.org/10.1016/j.trsl.2009.10.002

[28] Hussain, M., Bibi, S. and Javed, Q. (2011) Heritability of Genetic Variants of Resistin Gene in Patients with Coronary Artery Disease: A Family-Based Study. Clinical Biochemistry, 44, 618-622. http://dx.doi.org/10.1016/j.clinbiochem.2011.02.013

[29] Sheth, T., Nair, C., Nargundkar, M., Anand, S. and Yusuf, S. (1999) Cardiovascular and Cancer Mortality Canadians of European, South Asian, and Chinese Origin from 1979 to 1993: An Analysis of 1.2 Million Deaths. Canadian Medical Association Journal, 161, 132-138.

[30] McPherson, R., Pertsemlidis, A., Kavaslar, N., Stewart, A., Roberts, R., Cox, D.R., et al. (2007) A Common Allele on Chromosome 9 Associated with Coronary Heart Disease. Science, 316, 1488-1491. http://dx.doi.org/10.1126/science.1142447

[31] Helgadottir, A., Thorleifsson, G., Manolescu, A., Gretarsdottir, S., Blondal, T., Jonasdottir, A., et al. (2007) A Common Variant on Chromosome 9p21 Affects the Risk of Myocardial Infarction. Science, 316, 1491-1493. http://dx.doi.org/10.1126/science.1142842

[32] Preuss, M., König, I.R., Thompson, J.R., Erdmann, J., Absher, D., Assimes, T.L., et al. (2010) Design of the Coronary Artery Disease Genome-Wide Replication and Meta-Analysis (CARDIoGRAM) Study: A Genome-Wide Association Meta-Analysis Involving More than 22000 Cases and 60000 Controls. Circulation: Cardiovascular Genetics, 3, 1369-1376. http://dx.doi.org/10.1161/CIRCGENETICS.109.899443

[33] Zhuang, J., Peng, W., Li, H., Wang, W., Wei, Y., Li, W. and Xu, Y. (2012) Methylation of p15 ${ }^{I N K 4 b}$ and Expression of ANRIL on Chromosome 9p21 Are Associated with Coronary Artery Disease. PLoS ONE, 7, e47193. http://dx.doi.org/10.1371/journal.pone.0047193

[34] Javed, Q. and Murtaza, I. (2013) Therapeutic Potential of Tumor Necrosis Factor-Alpha Antagonists in Patients with Chronic Heart Failure. Heart, Lung and Circulation, 22, 323-327. http://dx.doi.org/10.1016/j.hlc.2012.12.002 
Scientific Research Publishing (SCIRP) is one of the largest Open Access journal publishers. It is currently publishing more than 200 open access, online, peer-reviewed journals covering a wide range of academic disciplines. SCIRP serves the worldwide academic communities and contributes to the progress and application of science with its publication.

Other selected journals from SCIRP are listed as below. Submit your manuscript to us via either submit@scirp.org or Online Submission Portal.
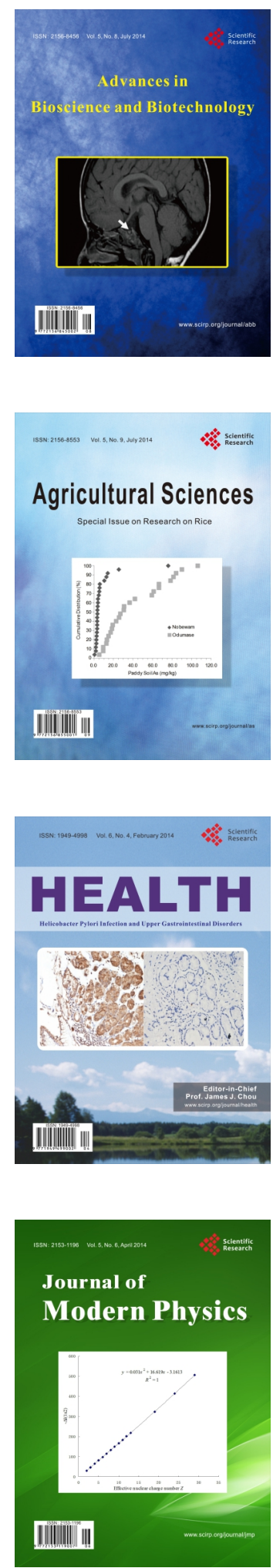
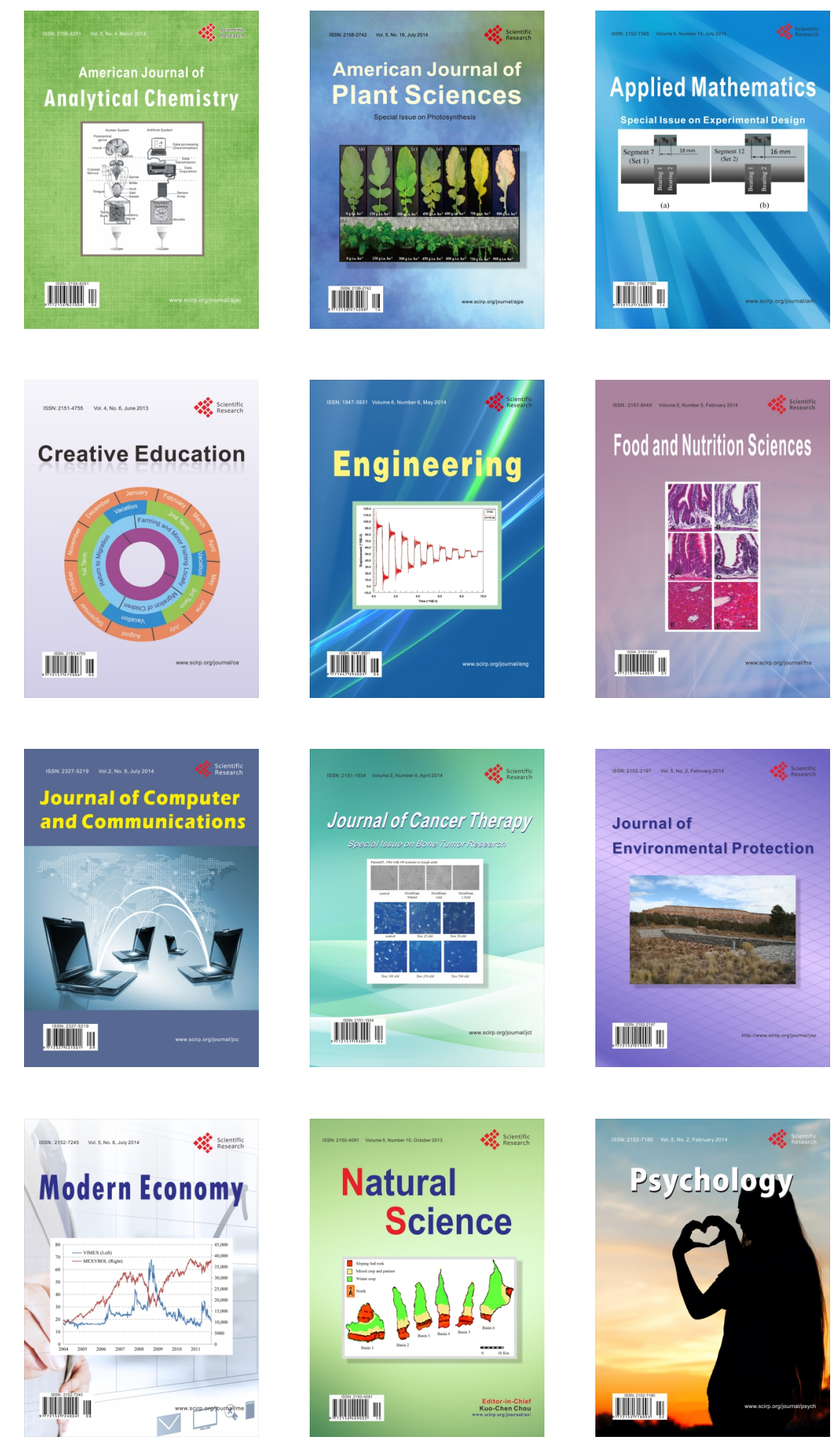